\title{
The End of Religion? Examining the Role of Religiousness, Materialism and Long-Term Orientation on Consumer Ethics in Indonesia
}

\begin{abstract}
Various studies on the impact of religiousness on consumer ethics have produced mixed results and suggested further clarification on the issue. Therefore, this article examines the effect of religiousness, materialism, and long-term orientation on consumer ethics in Indonesia. The results from 356 respondents in Indonesia, the largest Muslim population in the world, showed that intrinsic religiousness positively affected consumer ethics, while extrinsic social religiousness negatively affected consumer ethics. However, extrinsic personal religiousness did not affect consumer ethical beliefs dimensions. Unlike other studies in developed countries, materialism and long-term orientation influenced only a few of the consumer ethical beliefs dimensions in this study. To date, the study is one of the first empirical studies to explore the impact of religiousness on consumer ethics in Indonesia. The study contributes to the debate on the impact of religiousness on consumer ethics and can assist managers and public policymakers in their effort to mitigate unethical consumer activities in Indonesia.
\end{abstract}

Keywords: Consumer Ethics, Religiousness, Materialism, Long-term Orientation, Indonesia 


\section{Introduction}

Research on consumer ethics has increased in the last few decades as businesses began to understand the impact on consumer choices (e.g., Lu and Lu, 2009; Muncy and Vitell, 1992; Vitell et al., 2006; Vitell, 2009). In particular, various studies indicated a link between religion and business (Parboteeah et al., 2008; Vitell et al., 2001). Prominent researchers in the area of ethics, Hunt and Vitell (1993) included religion in their revised general theory of ethics, arguing that the strength of religiousness resulted in differences in individuals' decision making processes when they faced business decisions involving various ethical issues.

Nonetheless, evidence produced conflicting results when individuals perceived as high in religiousness committed unethical acts. One such anomaly is Indonesia, noted as a religious country with a high number of people believing in God (Suryadinata et al., 2003; Hermawan, 2013). More than nine in ten people in Indonesia report religion is very important and influences their political, cultural, and economic life (Pew Research, 2008). Nonetheless, various unethical practices remain prevalent and ingrained in everyday lives. For example, software piracy in Indonesia rose $1 \%$ to $87 \%$ in 2010 with the commercial value of unlicensed software installed on personal computers reaching $\$ 1.32$ billion US (Business Software Alliance, 2011). Another study revealed that over 95\% of movies sold on DVD in Indonesia were pirated copies and only $14 \%$ of respondents considered genuine copies when buying products (McGuire, 2009). Business Software Alliance's (2011) global study noted that the most frequent software pirates were disproportionately young and male and twice as likely to live in emerging economies. In addition, Indonesia faces several moral and ethical challenges. Corruption, a lack of transparency, an inability to enforce contracts, cronyism, and nepotism are some of the major concerns in conducting business in Indonesia. This has caused widespread cynicism and complicity in a culture accustomed to official dishonesty. 
Thus, previous evidence seemed to contradict the theory that religiousness would positively affect ethical decision making.

Therefore, the main purpose of this study is to examine the role of religiousness, materialism and long term orientation in consumer ethics, by extending the work of Vitell et al. (2006, 2007) and $\mathrm{Lu}$ and $\mathrm{Lu}$ (2010). Specifically, this research will provide us a greater understanding on the effects or impact of religiousness and non-religiousness dimensions (namely materialism and long term orientation) on consumer ethics ${ }^{1}$. The study can benefit businesses operating in Indonesia, especially in encouraging consumers to make ethical purchases. In addition, the study will contribute to the body of knowledge that investigates the link between religiousness, materialism, long-term orientation and consumer ethics.

\section{Literature Review}

To acquire further insights into the role of religiousness, materialism and long term orientation in consumer ethics, the literature review section will offer definitions and previous research findings on these issues. This section will begin by outlining the extant literature on consumer ethics followed by religiousness (intrinsic and extrinsic), materialism and finally, long-term orientation.

Consumer ethics. Consumer attitudes toward unethical practices have received considerable attentions in the last few decades (Vitell, 2003). Muncy and Vitell (1992) defined consumer ethics as "the moral principles and standards that guide behaviour of individuals or groups as they obtain, use and dispose of goods and services" (p. 298), and designed the most widely used construct of consumer ethics scales (CES). The scale examined consumers' ethical beliefs regarding questionable behaviour. The scale consisted of four dimensions, including: a) actively benefiting from illegal activities (ACTIVE), b)

\footnotetext{
${ }^{1}$ We thank an anonymous reviewer for this suggestion.
} 
passively benefiting (PASSIVE), c) actively benefiting from deceptive (or questionable, but legal) practices (LEGAL), and d) no harm/no foul activities (NO HARM). Most consumers reported it was more ethical to benefit from a passive activity than from an active/illegal activity. In addition, consumers noted that benefiting from a passive activity was more unethical than benefiting from deceptive but legal activities. Furthermore, the perception of no harm/no foul involvement was generally acceptable and considered more ethical than the other three beliefs (Vitell and Paolillo, 2003).

In 2003, Vitell summarized extant research on consumer ethics. The results showed research on consumer ethics mainly focused on consumers in developed countries, such as the United States (Albers-Millers, 1999; Bateman et al., 2002; Dodge et al., 1996; Garner et al., 1999; Muncy and Vitell, 1992; Muncy and Eastman, 1998; Rallapalli et al., 1994; Rawwas and Singhapakdi, 1998; Strutton et al., 1994; Vitell and Muncy, 1992; Vitell et al., 2001); Australia (Rawwas et al., 1996); Singapore (Ang et al., 2001); Hong Kong (Bateman et al., 2002); Japan (Erffmeyer et al., 1999); Germany, Denmark, Scotland, The Netherlands, Spain, Italy, Greece, and Portugal (Polonsky et al., 2001); Northern Ireland (Rawwas et al., 1998); and Belgium (Van Kenhove et al., 2001). Some studies investigated the issue in developing countries in the Middle-East, such as: Egypt ( Al-Khatib et al., 1995; Al-Khatib et al., 1997; Al-Khatib et. al., 2002; Rawwas, 2001; Rawwas et al. 1994); Lebanon (Rawwas, 2001; Rawwas et al., 1998); and Saudi Arabia, Oman, and Kuwait (Al-Khatib et al., 2005).

Only a few researchers examined consumers in Asia, including Malaysia (Singhapakdi et al., 1999), and Indonesia (Lu and Lu, 2010; Rawwas, 2001). Lu and Lu (2010) found that Indonesian consumers who displayed high ethical concern over actively benefiting from illegal activities had high levels of materialism. Moreover, materialistic consumers were more likely to engage in questionable unethical activities. 
Ethical judgement of consumers in the Asian market still received less attention than other regions did ( $\mathrm{Lu}$ and $\mathrm{Lu}, 2010)$. Thus, Vitell (2003) recommended more cross cultural research to examine the universality, or lack thereof, of consumer ethics. Moreover, most empirical research on consumer ethics adopted the consumer ethics scale of Muncy and Vitell (1992). Recently, Vitell and Muncy (2005) updated the scale by adding new items, which grouped into three distinct categories: a) downloading/buying counterfeit goods, b) recycling/environmental awareness, and c) doing the right thing/doing good. The current study is one of the first few research utilizing the updated CES developed by Vitell and Muncy (2005).

Intrinsic and Extrinsic Religiousness. Allport and Ross (1967) defined religious orientation as the extent to which a person lives out his or her religious beliefs. Similarly, McDaniel and Burnett (1990) defined religiousness as a belief in God followed by a commitment to follow rules and principles believed set by God. Decades of studies examined the influence of religions on an individual's ethical judgement, beliefs, and behaviour (e.g., Hunt and Vitell, 1986, 1993; McNichols and Zimmerer, 1985; Rashid and Ibrahim, 2007; Rawwas, 1996; Vitell and Paolillo, 2003; Vitell et al., 2005, 2006). Studies show that religiousness would have a positive effect on an individual's standard of ethics (Huffman, 1988; Giorgi and Marsh, 1990). Religious motivations can be viewed in terms of intrinsic and extrinsic religiousness which could differentiate religious motivation (Allport and Ross, 1967). The "extrinsically motivated person uses his religion, while intrinsically motivated person lives his religion" (Allport, 1967, p. 434). Therefore, there are different levels of religiousness. Intrinsically religiousness is the highest form of cognitive dimension. Someone with high intrinsic religiousness will consider the benefits of religion (e.g., meeting friends etc.) less importance compared to their relationship with 'God'. An individual with strong intrinsic religiousness tended to live daily life according to her or his religion (Vitell et al., 
2005). In contrast, extrinsic religiosity is a behavioral dimension of religiousness. An individual with strong intrinsic religiousness tended to live daily life according to her or his religion. In contrast, an individual with strong extrinsic religiousness might be more influenced by social determinants and participate in religious activities to meet personal needs (e.g., source of comfort and peace) or for social goals (e.g., social support). Vitell et al. (2005) confirmed that intrinsic religiousness was a significant personal characteristic that could explain consumer ethical judgements. In 2007, Vitell et al. included a new dimension on the consumer ethics scale, namely doing good/recycling. However, their study showed that intrinsic religiousness was not a significant predictor of the new dimensions.

Recently, Lu and Lu (2009) analysed consumer ethics in Indonesia but did not include the level of religiousness in their study. Religion plays a significant role in Indonesian life. Although a Gallup World survey showed that $99 \%$ of the respondents considered religion an important part of their daily life (Crabtree, 2010), most studies on consumer ethics failed to include religiousness as a determinant of consumer ethics (Cornwell et al., 2005; Goodwin and Goodwin, 1999). Similarly, Vitell and Paolillo (2003) noted few studies examined the role of religiousness in consumer ethics in spite of the fact that religiousness played a critical role in forming consumer values and beliefs. Therefore, there is a need to examine the effect of religiousness on consumer ethics.

Vitell et al. (2005) argued that individuals with a high degree of extrinsic religiousness might not be as committed to a religion as they appeared to be. Their study found that intrinsic religiousness was a determinant of consumer ethical beliefs, while extrinsic religiousness was not. In another study, Vitell et al. (2007) reported extrinsic religiousness was a significant predictor of consumer ethical dimensions (i.e., doing good/recycling) but not significant for the other four dimensions of consumer ethical beliefs. The extrinsic construct did not exactly measure religiousness but it measured an individual's 
attitude toward religion as a source of comfort and social support (Donahue, 1985). Moreover, most studies on consumer ethics and religiousness have not examined the differences between the effects of the two extrinsic religiousness on consumer ethics. Kirkpatrick (1988) suggested that extrinsic religiousness, as measured by Allport and Ross (1967), divided into two main categories, extrinsic personally oriented and extrinsic socially oriented. Similarly, other studies consistently distinguished different forms of extrinsic orientation, namely extrinsic social (Es), which showed religion used to fulfil an individual's social needs (e.g., meeting friends) and extrinsic personal (Ep), which indicated a religion used to fulfil personal needs (e.g., comfort) (Fulton et al. 1999; Gorsuch and McPherson, 1989; Socha, 1989).

Materialism. Materialism has received consistent attention in consumer research (e.g., Belk, 1985; Burroughs and Rindfleisch, 2002; Lu and Lu, 2010; Muncy and Vitell, 1998; Vitell et al., 2006). Ward and Wackman (1971) operationally defined materialism as "an orientation emphasizing possession and money for personal happiness and social progress" (p. 426) or, according to Richins and Dawson (1992), materialism could be a "set of centrally held beliefs about the importance of possession on one's life" (p. 308). Similarly, Moschis and Churcill, 1978, (p. 607) defined materialistic attitude as "orientation emphasizing possessions and money for personal happiness and social progress (1978). Materialism could link to certain types of unethical behaviour and could become the focus of one's life, above religion, friends, and other achievements (Barret, 1992; Richins and Dawson, 1992).

Research on materialism and ethics produced mixed results. Some studies suggested that materialism and consumer ethics negatively correlated, where materialistic consumers are often willing to bend ethical rules to increase their possessions. For example, Ferrell and Gresham (1985) found managers who felt pressured to succeed (i.e., make profit) were more 
likely to exhibit unethical behaviour. There is greater possibility for them to engage in unethical behaviour to achieve the desired profitability. Similarly, Martin (2003) reported that materialism and ethics negatively correlated among generation $\mathrm{X}$ in the United States and among consumers in China (Forden, 1993). Environmentalism also negatively correlated with materialism (Banerjee and McKeage, 1994). When possessions become the focus of one's life, they become more important than religion and relationships with friends (Richins and Dawson, 1992).

In contrast, another group of studies suggested that materialism had no relationship to ethical judgement. For example, LaBarbera and Gurham (1997) found the non-generosity and envy dimensions of materialism negatively related to the well-being of 'born-again' Christians but not for Christians that did not profess to being born again. Similarly, Mick (1996) found that, after controlling for the effects of socially desirable responding, no correlation existed between materialism and self-esteem. Also, Pinto et al. (2000) found no significant differences between students with low materialism versus student with high materialism on the number of credit cards owned and the amount owed.

As a result, studies suggested that materialism was a constructed manifestation that differed according to the culturally based value systems of a particular society (Burroughs and Rindfleisch, 2002; Holt, 1998). Therefore, more studies are needed to examine incongruent results using research in different contexts (Vitell, 2003).

Long-term orientation. Hofstede (1980) initially developed long-term orientation (LTO), rooted in Confucian values concerning time, tradition, perseverance, saving for future, and allowing others to "save face." Hofstede (2001) defined LTO as "the fostering of virtues oriented towards future rewards, in particular, perseverance and thrift" (p. 359). Its opposite pole, Short Term Orientation, stands for "the fostering of virtues related to the past and the present, in particular, respect for tradition, preservation of face and fulfilling social 
obligations" (Hosfstede, 2001, p. 359). Bearden et al. (2006) added to the definition as "the cultural value of viewing time holistically, valuing both the past and the future rather than deeming actions important only for their effects in the here and now or the short term. As such, individuals scoring high in LTO value planning, tradition, hard work for future benefit, and perseverance" (p. 457). In summary, the conceptualization of LTO was as a forwardlooking (i.e., future, long-term) and past-looking (i.e., now, short-term) view with two subdimensions, tradition and planning (Bearden et al., 2006). However, in the last few years, academics have relied predominantly on Hofstede's (1980) conceptualization of LTO (Bond, 2002). Nevins et al. (2006) suggested that consumers high in the planning and traditional aspects of LTO would also hold high levels of ethical values. Researchers theorized that those with higher LTO in Asia would have a higher level of ethical values (Moon and Franke, 2000; Tsui and Windsor, 2001). Chinese business managers who have high LTO were found to have higher standards of business ethics (Ip, 2003). Moreover, LTO is also correlated with environmental responsibility and integrity (Christie et al., 2003).

Most studies on LTO used Hofstede's typology, which focused on cultural groupings and not on individuals. Nevertheless, studies revealed limitations surrounding Hofstede's scale, which indicated problems of applying aggregate-level measure to the individual level (Bearden et al., 2006; Bond 2002). Consequently, Bearden et al. (2006) proposed a new construct to examine differences in behaviour caused by time orientation in individuals, such as tradition or respecting someone's past, and planning, which includes preparing for the future. Despite the postulating and theorizing, there was still little empirical evidence examining the impact of long-term orientation on consumer ethics at the individual level, especially in the context of developing countries. One study in the U.S. found that a longterm perspective on tradition and planning indeed influenced higher levels of ethical values 
(Nevins et al., 2006). Thus, this study will also examine the impact of LTO on consumer ethics.

\section{Hypotheses}

Based on the previously discussed theoretical and empirical literature, the study proposes several hypotheses which explore the impact of religiousness dimensions (i.e. intrinsic religiousness, extrinsic religiousness) and non-religiousness dimensions (i.e. materialism and long term orientation) on consumer ethics.

Intrinsic religiousness. Personal religiousness provides a basic understanding to explore the nature of an individual's ethical behaviour (Magill, 1992; Vitell, 2005). Studies found that intrinsic religiousness significantly influence consumers' ethical judgement (Kennedy and Lawton, 1998; Giorgio and Marsh, 1990; Vitell, et al., 2005). People with high intrinsic religiousness tended to have more concern with higher moral standards (Weibe and Fleck, 1980). Based on the previous discussion, it is reasonable to believe that individuals with high intrinsic religiousness would place a high degree of importance on religion thus making these individuals more ethically aware. Thus, we hypothesize the following:

$\mathbf{H}_{\mathbf{1}}$ : Intrinsic religiousness is a positive determinant of consumer ethical beliefs regarding: (a) "active, illegal" dimension; (b) "passive" dimension; (c) "active, legal" dimension; (d) "no harm/no foul" dimension; (e) "downloading" dimension; (f) "recycling"; (g) "doing good".

Extrinsic religiousness. Vitell et al. (2005) suggest that individuals with a high degree of extrinsic religiousness might not necessarily be committed to his/her religion as they might appear to be, thus, might not be ethically sensitive compared to individuals with high intrinsic religiousness. Extrinsic religiousness was found to be correlated less with religious commitment (Donahue, 1985). Thus, we will test the following hypotheses:

$\mathbf{H}_{2}$ : Extrinsic religiousness (social and personal) is not a significant determinant of consumer ethical beliefs regarding: (a) "active, illegal" dimension; (b) "passive" dimension; (c) "active, legal" dimension; (d) "no harm/no foul" dimension; (e) "downloading" dimension; (f) "recycling”; (g) “doing good". 
Materialism. Some studies showed that materialism is negatively correlated with the ethical standard of consumers (Muncy and Eastman, 1998). Individuals with more materialistic value differed from those who were less materialistic. Certain unethical behaviors are associated with higher levels of materialism (Barret, 1992). Despite inconclusive findings, as previously discussed, on the impact of materialism on consumer ethics, we offer the following hypotheses:

$\mathbf{H}_{3}$ : Materialism is a negative determinant of consumer ethical beliefs regarding: (a) "active, illegal" dimension; (b) "passive" dimension; (c) "active, legal" dimension; (d) "no harm/no foul" dimension; (e) "downloading" dimension; (f) "recycling"; (g) "doing good".

Long-term orientation. Findings showed that individuals with higher LTO orientation have been shown to have high levels of ethical values (Moon and Franke, 2000; Nevins et al., 2006; Tsui and Windsor, 2001). Unethical behaviour violated the traditional values of honesty and integrity that high LTO individuals care about (Nevins et al., 2006). Individuals who value LTO will exhibit a high degree of ethical values. Thus, we propose the following hypotheses:

$\mathbf{H}_{\mathbf{4}}$ : Long-term orientation (tradition and planning) is a positive determinant of consumer ethical beliefs regarding: (a) "active, illegal" dimension; (b) "passive" dimension; (c) "active, legal" dimension; (d) "no harm/no foul" dimension; (e) "downloading" dimension; (f) "recycling"; (g) "doing good".

\section{Methodology}

Research context. Indonesia is the fourth most populous nation in the world with around 240 million people and the largest country in Southeast Asia (Population Reference Bureau, 2011). Indonesia is a country of cultural diversity and home to the largest Muslim population in the world with $86.1 \%$ of the population, followed by $8.7 \%$ Christian/Catholic, 
$1.8 \%$ Hindu, and $3.4 \%$ other. With the exception of China, the Indonesian economy is growing faster than other major emerging market economies with 6.5\% growth in 2011 (CIA World Factbook, 2013). The Gross Domestic Product (GDP) per capita was $\$ 5,000$ (est) in 2012, with unemployment rate of $6.1 \%$ and $11.7 \%$ lived below the poverty line in 2012 (CIA World Factbook, 2013).

Sample. Data derived from a convenience sampling at three large universities (i.e., one public and two private universities) in Yogyakarta, Indonesia. Researchers handdelivered approximately 450 questionnaires to students in classrooms and public spaces (e.g., canteens and lounge rooms) of the universities. Of the 450 questionnaires, participants returned 397, indicating a response rate of $88.2 \%$. However, of the 397 questionnaires returned, only 356 were usable offering an overall response rate of $79 \%$. Male and female respondents were almost equal in number, $55 \%$ and $45 \%$, respectively. Most were single ( $97 \%$ ) with $48 \%$ between the ages of $18-20$ years and $39 \%$ between the ages of $21-23$. The majority was Muslims (49\%), followed by Christians/Catholics (29\%). Table 1 summarises the demographic profile of respondents.

\section{Insert Table 1 about Here}

Measurement instrument and reliability. The instrument comprised six sections. The first section included the revised Muncy and Vitell (1992) consumers' ethical beliefs scale available in Vitell and Muncy (2005) and using a 28-item scale. The reliability of the five dimensions on the consumer ethics scale was as follows: ACTIVE ( 5 items; $\alpha=0.715$ ), PASSIVE ( 2 items; $\alpha=0.614)$, LEGAL ( 2 items; $\alpha=0.727)$, NO HARM/ NO FOUL (3 items; $\alpha=0.534$ ), DOWNLOADING (2 items; $\alpha=0.409$ ), RECYCLING ( 2 items; $\alpha=$ 0.722), and DOING GOOD ( 3 items; $\alpha=626$ ). Respondents rated each behaviour on a 5point Likert-type scale ranging from $1=$ strongly disagree to $5=$ strongly agree. Therefore, a high score on the scale indicated that consumers considered a particular action as more 
acceptable or less unethical. In this study, no harm/no foul and downloading has low reliability. Due to the prevalence of software piracy in Indonesia, some of the items in the no harm/no foul are more acceptable than the other such as: 'Installing software on your computer without buying it'; 'Burning a CD instead of buying it'; 'Using computer software or games that you did not buy'; versus 'Spending over an hour trying on different dresses and not purchasing any'. Similarly, the downloading dimensions also produced low reliability as the scale measures two different behaviors: 'Downloading music from the internet instead of buying it' and 'Buying counterfeit goods instead of buying the original manufacturers' brands'. Thus, future research should be aimed at developing an updated scale specifically looking at the ethicality of buying pirated software and buying counterfeit brands.

The second section included Moschis and Churchill's (1978) six-item materialistic attitude scale with a Cronbach alpha reliability coefficient of 0.890 ( 3 items). The third section included the revised Allport and Ross (1967) scale, measuring intrinsic, extrinsic social and extrinsic personal dimensions. The revised intrinsic/extrinsic religiousness scales adapted from Allport and Ross (1967) by Kirkpatrick (1988) measured religiousness. Allport's Religious Orientation Scale (ROS) is one of the most frequently used measures to determine the degree to which a person internalises and practices religious beliefs and values (Donahue, 1985; Vitell et al., 2009). As previously discussed, extrinsic religiousness divided into two categories, "Es" for socially oriented extrinsic items and "Ep" for personally oriented extrinsic items. Slight changes in the wording allowed the scales to measure religion in general rather than a specific religion. For example, the wording "attending church" changed to "attending religious services" (Vitell et al., 2005). The intrinsic dimension contained eight items, exemplified by items such as, "I try hard to live all my life according to my religious beliefs." This dimension exhibited a reliability coefficient of 0.831 . The 
extrinsic dimension included six items. Items such as "I go to religious services mostly to spend time with my friends" exemplified extrinsic social with a reliability of 0.929 . Items such as "I pray mainly to gain relief and protection" exemplified extrinsic personal with a reliability of 0.772 .

The fourth section contained eight items of the long-term orientation scale by Bearden et al. (2006) to measure tradition and planning. Reliability of the LTO tradition was 0.509 and LTO planning was 0.628 . The last section consisted of various demographic measures (i.e., age, gender, marital status, and religion). The scale items are listed in Table 2.

\section{Insert Table 2 about Here}

\section{Results and Discussions}

Researchers employed separate multiple regression analyses to review the data and test the hypotheses for intrinsic religiousness, extrinsic social and personal religiousness, materialism, and long-term orientation tradition and planning scales as the independent variables and the seven dimensions of consumer ethics as the dependent variables. Table 3 shows the correlation matrix for the independent and dependent variables with coefficient alphas appearing on the diagonal. Examining the relationships between the independent variables and each of the seven dependent variables required running seven separate multiple regression analyses.

Consumer Ethics Dimensions. All of the dimensions of the CES yielded high and low value models with the independent construct as determinants. The seven models had $R^{2}$ values of 0.423 (active), 0.236 (passive), 0.302 (legal), 0.302 (no harm/no foul), 0.099 (downloading), 0.148 (recycling), and 0.429 (doing good). Table 4 reports the results of these regression analyses.

Insert Table 3 and 4 about Here 
Religiousness. Table 4 shows that intrinsic religiousness significantly explained consumer ethical beliefs for actively/illegal, passive, active/legal and doing good but not for no harm/no foul, downloading, and recycling. Similar to Vitell et al.'s $(2006,2007)$ findings, the study also found that the stronger an individual's sense of intrinsic religiousness, the more likely he or she was to judge various 'questionable' consumer activities as wrong; thus, generally supporting $\mathrm{H}_{1 \mathrm{a} \_a c t i v e, i l l e g a l}, \mathrm{H}_{1 \mathrm{~b} \_ \text {passive }}, \mathrm{H}_{1 \mathrm{c} \_ \text {active,legal, }}$ and $\mathrm{H}_{1 \mathrm{~g} \_ \text {doinggood. }}$ There was no

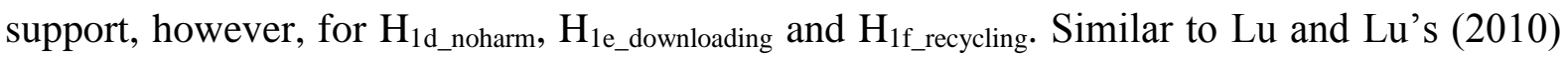
findings, questions related to no harm/no foul and downloading or software piracy related questions showed higher mean values compared to other consumer ethics dimensions. Therefore, Indonesian consumers perceive these activities as acceptable, which explains why the digital software piracy in general and software piracy in particular is extremely high in Indonesia, especially among young consumers. Interestingly, this study specifically showed that even individuals with high intrinsic religiousness did not consider downloading and notrecycling as unethical activities. Religious institutions need to emphasise that downloading pirated software is an act of 'stealing' which therefore is incongruent with the religious teachings. In addition, recycling needs to be taught as an act of preserving and maintaining the earth which was given by 'God'. When believers changed their perspectives, their behaviours will be altered consequently. In addition, the Indonesian government and business communities need to educate people about intellectual property rights and the consequences of piracy on the Indonesian music, film, publishing and other creative industries. All these efforts will significantly change consumer perspectives in Indonesia where a majority of them claimed to be religious. Overall, an intrinsic religious orientation appeared to explain consumer ethics beliefs in Indonesia, showing that religious orientation could cause viewing questionable behaviour as wrong. 
Moreover, results which examined extrinsic social and extrinsic personal religiousness produced mixed findings. Results revealed that extrinsic social religiousness significantly explained consumer ethical beliefs for six of the seven dimensions with the exception of recycling. Findings did not support $\mathrm{H}_{2 \mathrm{a} \_ \text {active,illegal }}, \mathrm{H}_{2 \mathrm{~b} \_ \text {passive, }} \mathrm{H}_{2 \mathrm{c} \_ \text {active,legal }}$,

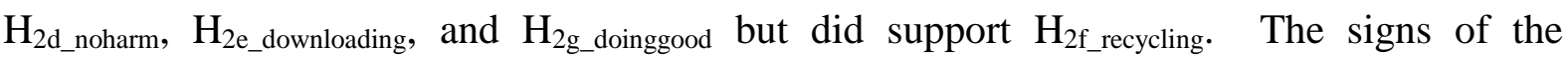
respective beta weights were in the expected directions. Thus, an individual with a stronger extrinsic social religiousness would be more likely to view questionable consumer activities (i.e., active, passive, legal, and downloading) as acceptable (not wrong) actions. Moreover, they would be less likely to view no harm/no foul as wrong and less likely to support doing good to others. Subsequently, in contrast, extrinsic personal religiousness did not significantly explain all consumer ethics dimensions. Thus, the analyses supported all hypotheses: $\mathrm{H}_{2 \mathrm{a} \_a c t i v e, i l l e g a l}, \mathrm{H}_{2 \mathrm{~b} \_ \text {passive }}, \mathrm{H}_{2 \mathrm{c} \_ \text {active,legal }}, \mathrm{H}_{2 \mathrm{~d} \_n o h a r m}, \mathrm{H}_{2 \mathrm{e} \_ \text {downloading }}, \mathrm{H}_{2 \mathrm{f} \_ \text {recycling }}$ and

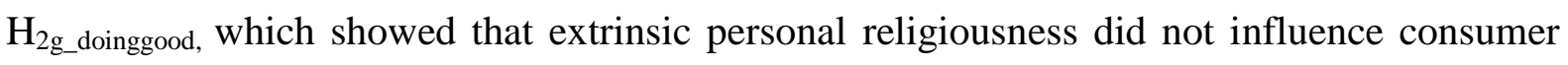
ethics. Most of the directions of beta weights were in the expected directions. It reveals that extrinsic personal does not determine whether one views questionable consumer behaviours as wrong, which may explain why an individual perceived as having a high level of religiousness commits unethical acts. For example, recently, authorities detained a leader of a religious-based political party in Indonesia over a beef import corruption case (Bachelard, 2013). Regardless of their core beliefs, these individuals have used religion as a means to achieve social acceptance and climb the social ladder, which brings various social, economic, and political benefits. Specifically, we argue that an extrinsic personal construct does not measure religiousness per se as suggested by Donahue (1985).

Materialism. Materialism significantly explained only no harm/no foul, downloading, and recycling. The signs of the beta weights were in the expected direction. Thus, someone with high materialistic value will view no harm/no foul and downloading as 
not being wrong and interestingly, she/he is more likely to recycle. Nonetheless, materialism did not significantly explain the active/illegal, passive, active/legal and doing good. Thus, findings support $\mathrm{H}_{3 \mathrm{~d} \_ \text {noharm }}$ and $\mathrm{H}_{3 \mathrm{e} \_ \text {downloading }}$ but did not support $\mathrm{H}_{3 \mathrm{a} \_ \text {active,illegal }}, \mathrm{H}_{3 \mathrm{~b} \_ \text {passive, }}$ $\mathrm{H}_{3 \mathrm{c} \_a c t i v e, \text { legal }}, \mathrm{H}_{3 \mathrm{f} \_ \text {recycling, }}$, and $\mathrm{H}_{3 \mathrm{~g} \_ \text {doinggood. }}$ Consequently, a materialistic person is not always likely to view these questionable behaviours as not being wrong. It can be suggested that as an individual starts their materialistic quests, ethical values may become less important. Nonetheless, in the context of a developing country, these individuals did not want to break the legal boundaries. They are willing to take advantage only when there are no legal consequences or at least when they perceive that the legal threat is minimum. Thus, they want to acquire material possessions within the acceptable boundaries of the society such as no/harm/no foul, downloading and recycling activities. Overall, materialism partially impacted individuals' views of the ethicality of questionable behaviour.

Long-term orientation. Long-term (tradition) orientation did not significantly explain consumers' ethical beliefs except for the active/illegal dimension and the no harm/no foul dimension with the negative and positive beta values, respectively. Results revealed that an individual with a strong tradition was more likely to perceive active illegal dimension as being wrong but view no harm/no foul as not being wrong. Thus, findings supported $\mathrm{H}_{4 \mathrm{~d} \_ \text {active/illegal }}$ but not $\mathrm{H}_{4 \mathrm{~d} \_ \text {noharm }}$ due to the opposite beta value. In summary, results did not support $\mathrm{H}_{4 \mathrm{~b} \_ \text {passive }}, \mathrm{H}_{4 \mathrm{c} \_ \text {active,legal }}, \mathrm{H}_{4 \mathrm{~d} \_ \text {noharm, }} \mathrm{H}_{4 \mathrm{e} \_ \text {downloading, }} \mathrm{H}_{4 \mathrm{f} \_ \text {recycling }}$ and $\mathrm{H}_{4 \mathrm{f} \_ \text {doinggood. }}$ It shows that individuals who prize tradition are less likely to agree on actively benefiting illegal activities but are more likely to agree on no/harm no foul dimensions. Furthermore, long-term (planning) orientation did not significantly explain consumer's ethical beliefs with the exception of doing good. Thus, someone with high long-term planning was more likely to view doing good as not being wrong, supporting $\mathrm{H}_{4 \mathrm{~g} \_ \text {doinggood }}$ but not supporting $\mathrm{H}_{4 \mathrm{a} \_a c t i v e, i l l e g a l}$, $\mathrm{H}_{4 \mathrm{~b} \_ \text {passive }}, \mathrm{H}_{4 \mathrm{c} \_ \text {active,legal }}, \mathrm{H}_{4 \mathrm{~d} \_ \text {noharm }}, \mathrm{H}_{4 \mathrm{e} \_ \text {donwloading }}$, and $\mathrm{H}_{4 \mathrm{f} \_ \text {recycling. }}$ In the context of Indonesia, 
an individual who prized tradition and planning did not always possess higher ethical values. Table 5 summarized all hypotheses.

\section{Insert Table 5 About Here}

\section{Conclusions}

Given the above results, our study makes some contributions to the study of the relationship between religiousness, materialism, long-term orientation and consumer ethics. In addition, the reliability values of consumer ethics show some insights into how Indonesians perceived consumer ethics and the influence of religiousness, materialism and long-term orientation on ethics. ${ }^{2}$ The dimension from the highest to lowest are doing good, followed by active, legal, no-harm and passive, while recycling and downloading were the last two. Our empirical analysis generates four major results. First, intrinsic religiousness appeared to explain particular attitudes toward questionable behaviours. Those having stronger intrinsic religiousness were more likely to believe that the consumer activities presented were unethical (i.e., active, passive, legal dimensions) and ethical for "doing good" dimension. The no harm/no foul dimension failed to relate significantly to an intrinsic religious orientation, which is consistent with Vitell et al.'s $(2006,2007)$ findings. In the context of Indonesia, respondents perceived no harm/no foul dimensions, downloading, and recycling as not harmful to others.

Second results which examined extrinsic social and extrinsic personal religiousness produced mixed findings. On the one hand, extrinsic social was a factor in determining an individual's attitude toward questionable consumer practices, except for recycling. On the other hand, the dimension of extrinsic personal did not significantly explain any of the consumer ethics dimensions. Thus, extrinsic personal does not determine whether one views questionable consumer behaviours as wrong.

\footnotetext{
${ }^{2}$ We thank an anonymous reviewer for this suggestion.
} 
Third, Vitell et al. (2005), using a sample from a developed country (i.e., the US), found that materialism explained passive, active/legal and no harm. Nonetheless, the results of our study revealed that materialism did not explain various unethical behaviours except for the no harm/no foul and the new dimensions of downloading and recycling dimensions.

Finally, long-term orientation (tradition) explained only the active and no harm/no foul dimensions, while long-term orientation (planning) explained only the doing good dimension.

Consequently, when we asked the question, "is it the end of religion?" we may suggest that religiousness still influences consumers' ethical decision making in Indonesia. As previously mentioned, those with higher intrinsic religiousness and extrinsic social religiousness have different attitudes toward consumer ethics. Interestingly, individuals who live in developing countries perceive these ethical and unethical activities differently than individuals in the developed countries. Consumers in Indonesia have not seen the ethical ramifications of downloading and recycling activities. As recent phenomena, the two activities have not been strongly embedded in most religious teachings. Thus, reducing the importance of buying genuine products and recycling. In addition, the young generations may have different personal values and may have different views of the 'right and incorrect' attitudes toward stealing and recycling activities ${ }^{3}$.

Our study adds to conceptual base of what may explain the formation of unethical activities. It is not that these individuals want to commit unethical behaviours but they still categorise these activities as ethically acceptable by the society. Through this study, business school teachers, religious leaders and public policy makers can benefit through better understanding of how individuals with intrinsic and extrinsic religiousness view consumer

\footnotetext{
${ }^{3}$ We thank an anonymous reviewer for this suggestion.
} 
ethics. Applying this understanding could lead to better ethical choices among consumers in Indonesia.

\section{Limitations and Future Research}

Limitations are inevitable in any convenience sampling. Similar to other ethical studies that used student populations (e.g., Burnet et al., 2003; Nevins, et al., 2007), our samples derived from student populations in one city in Indonesia. The absence of correlation between long-term orientation and consumer ethics might be due to the younger population in this study because they may lack well formulated long-term orientation (Nevins et al., 2007). In addition, we did not include the ethnic origin of the respondents. As previously mentioned, Indonesia is an ethnically diverse country, thus ethnicity may influence religiousness and vice versa $^{4}$. Thus limits the generalizability of the findings. Future research should obtain data from other demographic categories (i.e., age, income and ethnic) in other cities in Indonesia, which may produce more generalizable results. Therefore, expanding the sample demographics is necessary. In addition, future research may closely examine why those with higher intrinsic religiousness still commit unethical acts. Despite the mentioned limitations, our results revealed intrinsic religiousness has an important influence on consumer ethics and thus individuals' religiousness cannot be dismissed in consumer ethics' research especially in the context of developing countries.

\footnotetext{
${ }^{4}$ We thank an anonymous reviewer for this suggestion.
} 


\section{References}

Albers-Miller, N. (1999). Consumer misbehavior: Why people buy illicit goods. Journal of Consumer Marketing 16(3), 273-287.

Allport, G.W. (1950). The individual and his religion: a psychological Interpretation (MacMillan, New York).

Allport, G. W. and Ross, J. M. (1967). Personal religious orientation and prejudice. Journal of Personality and Social Psychology 5, 447-457.

Al-Khatib, J. A., Dobie, K. and Vitell, S. J. (1995). Consumer ethics in developing countries: An empirical investigation. Journal of EuroMarketing 4(2), 87-105.

Al-Khatib, J. A., Robertson, C., Al-Habib, M. and Scott J. Vitell, S. J. (2002). Ethical beliefs and orientations in the Middle East: Are Arab consumers alike? Unpublished working paper.

Al-Khatib, J. A., Stanton, A. D. and Rawwas, M. Y. A. (2005). Ethical segmentation of consumers in developing countries: A comparative analysis. International Marketing Review $22(2), 225-246$

Al-Khatib, J., Vitell, S. J. and Rawwas, M. Y. A. (1997). Consumer ethics: A cross-cultural investigation. European Journal of Marketing 31(11/12), 750-767.

Ang, S. H., Cheng, P. S., Lim, A. C. and Tambyat, S. K. (2001). Spot the difference: Consumer responses towards counterfeit. Journal of Consumer Marketing 18(3), 219-235.

Bachelard, M. (2013). Beef importer with Australian links caught in quota bribe case. Retrieved from: http://www.canberratimes.com.au/national/beef-importer-with-australianlinks-caught-in-quota-bribe-case-20130131-2dnh6.html.

Banerjee, B. and McKeage, K. (1994). How green is my value: Exploring the relationship between environmentalism and materialism. Advances in Consumer Research 21, 147-152.

Barrett, M. (1992). Words and things: Materialism and method in contemporary feminist analysis. In M. Barrett \& A. Phillips (eds.), Destabilizing theory: Contemporary feminist debates (pp. 201-219). Oxford: Polity.

Bateman, C. R., Fraedrich, J. P. and Iyer. R. (2002, March). Framing effects within the ethical decision making process of consumers. Journal of Business Ethics 36, 119-140.

Bearden, W. O., Money, R. B. and Nevins, J. L. (2006). A measure of long-term orientation: Development and validation. Journal of the Academy of Marketing Science 34(3), 456-467.

Belk, R. W. (1985). Materialism: Trait aspects of living in the material world. Journal of Consumer Research 12(12), 265-280.

Bond, M. H. (2002). Reclaiming the individual from Hofstede's Ecological Analysis: A 20 year odyssey: Comment on Oyserman et al. Psychological Bulletin 128(1), 73-77. 
Bucic, T., Harris, J. and Arli, D. (2012). Ethical consumers among the millennials: A crossnational study. Journal of Business Ethics 110(1), 113-131.

Burnett, M., Keith, N. and Pettijohn, C. (2003, Spring). An empirical analysis of factors influencing student reactions to ethical advertising dilemmas: Educational experience, work experience, ethical philosophy, and demographics. Marketing Education Review 13, 33-46.

Burrough, J. E. and Rindfleisch, A. (2002). Materialism and well-being: A conflicting values perspective. Journal of Consumer Research 29(3), 348-370.

Business Software Alliance. (2011). Well over half the world's computer users admit pirating software, BSA study finds. Retrieved from http://www.bsa.org/country/News\%20and\%20Events/News\%20Archives/global/05152012idc-globalpiracystudy.aspx?sc_lang=en

Chan, A., Wong, S. and Paul Leung, P. (1998, August). Ethical beliefs of Chinese consumers in Hong Kong. Journal of Business Ethics 17, 1163-1170.

CIA World FAcbook (2013). Indonesia. Retrieved from: https://www.cia.gov/library/publications/the-world-factbook/geos/id.html

Cornwell, T. B., Weeks, C. S., \& Roy, D. P. (2005). Sponsorship-linked marketing: Opening the black box. Journal of Advertising 34(2), 21-42.

Crabtree, S. (2010). Religiousness highest in world's poorest nations. Retrieved from http://www.gallup.com/poll/142727/religiousness-highest-world-poorest-nations.aspx

Dodge, H. R., Edwards, E. A. and Fullerton, S. (1996, December). Consumer transgressions in the marketplace: Consumers' perspectives. Psychology and Marketing 13, 821-835.

Donahue, M .J. (1985). Intrinsic and extrinsic religiousness: Review and meta analysis. Journal of Personality and Social Psychology 48(2), 400-419.

Erffmeyer, R., Keillor, B. and Thorne LeClair, D. L. (1999, January). An empirical investigation of Japanese consumer ethics. Journal of Business Ethics 18, 35-50.

Ferrell, O. C. and Gresham, L. G. (1985, Summer). A contingency framework for understanding ethical decision making in marketing. Journal of Marketing 49, 87-96.

Forden, S. G. (1993). China embraces new revolution: Designer fashion. WWD 165(98), 1-3.

Fulton, A. S. and Gorsuch, R. L. (1999). Religious orientation, antihomosexual sentiment and fundamentalism among Christians. Journal for the Scientific Study of Religion 38, 14-22.

Gardner, D. M., Harris, J. and Kim, J. (1999). The fraudulent consumer. In G. Gundlach, W. Wilkie and P. Murphy (eds.), Marketing and Public Policy Conference Proceedings, (pp. 4854).

Giorgi, L., and Marsh, C. (1990). The Protestant work ethic as a cultural phenomenon. European Journal of Social Psychology 20(6), 499-517. 
Goodwin, J. and Goodwin, D. (1999). Ethical judgement across cultures: A comparison between business students from Malaysia and New Zealand. Journal of Business Ethics 18, 267-281.

Gorsuch, R. L. and McPherson, S. E. (1989). Intrinsic/extrinsic measurement: I/E-revised and single-item scales: Research note. Journal for the Scientific Study of Religion 28(3), 349-354.

Hermawan, A. (2013). Is Pew really saying most Indonesians are Muslim radicals? Jakarta Post May $3^{\text {rd }}, 2$.

Hofstede, G. (1980). Culture's consequences, 2nd edition. Sage Publications, Beverly Hills, CA.

Hofstede, G. (2001). Culture's consequences, Comparing values, behaviors, institutions and organizations across nations (Second edition). Thousand Oaks, CA: Sage.

Holt, D. B. (1998). Does cultural capital structure American consumption. Journal of Consumer Research 25(6), 1-25.

Huffman, T. E. (1988). In the world but not of the world: Religious, alienation, and philosophy of human nature among bible college and liberal arts college students, doctoral dissertation. Iowa State University, Ames, IA.

Hunt, S. D. and Vitell, S. J. (1986). A general theory of marketing ethics. Journal of Macromarketing 8, 30-42.

Hunt, S. D. and Vitell, S. J. (1993). The general theory of marketing ethics: A retrospective and revision. In N. C. Smith and J. A Quelch (eds.), Ethics in marketing (pp. 775-784), Irwin, Homewood, IL.

Ip, P. K. (2003) Business Ethics in a State-Owned Enterprise in China. Business Ethics: A European Review 12(1), 64-77.

Jakarta Post. (2011). The rise of religion in public space not a problem: Experts. Retrieved from http://www.thejakartapost.com/news/2011/04/28/the-rise-religion-public-space-not-aproblem-experts.html.

Kennedy, E. J. and Lawton, L. (1998). Religiousness and business ethics. Journal of Business 17(2), 163-175.

Kusuma, A. N. and Rahadiana, R. (2012). Direct investment pours into Indonesia despite worries. Retrieved from http://www.reuters.com/article/2012/10/22/us-indonesia-economyfdi-idUSBRE89L04220121022

LaBarbera, P. and Gurhan, Z. (1997). The role of materialism, religiousness, and demographics in subjective well-being. Psychology and Marketing, 14(1), 273-297.

Lockard, J. S. and Paulhus, D. L. (Eds.). (1988). Self-deception: An adaptive mechanism. Prentice-Hall, Upper Saddle River, NJ. 
Lu, L-C. and Lu, C-J. (2010). Moral philosophy, materialism, and consumer ethics: An exploratory study in Indonesia. Journal of Business Ethics 94, 193-210.

Magill, (1992). Theology in business ethics: appealing to the religiousness imagination. Journal of Business Ethics 11, 129-135.

McDaniel, S. W. and Burnett, J. J. (1990). Consumer religiousness and retail store evaluative criteria. Journal of the Academy of Marketing Science 18(2), 101-112.

McNichols, C. W. and Zimmerer, T. W. (1985). Situational ethics: An empirical study of differentiators of students' attitudes. Journal of Business Ethics 4(3), 174-180.

Martin, N. M. (2003). Materialism, ethics and generation X: An expansion of Muncy \& Eastman's 1998 study of the correlation between materialism and ethics, Unpublished doctoral dissertation, Nova Southeastern University,.

Mick, D. G. (1996). Are studies of dark side variables confounded by socially desirable responding: The case of materialism. Journal of Consumer Research 23(9), 106-119.

Moon, Y. S. and Franke, G. R. (2000). Cultural influences on agency practitioners. Journal of Advertising 29(1), 51-65.

Moschis, G. P. and Churchill, G. A. (1978). Consumer socialization: A theoretical and empirical analysis. Journal of Marketing Research 15(4), 599-609.

Muncy, J. A. and Eastman, J. K. (1998). Materialism and consumer ethics: An exploratory study. Journal of Business Ethics 171(1), 137-145.

Muncy, J. A. and Vitell, S. J. (1992). Consumer ethics: An empirical investigation of the ethical beliefs of the final consumer. Journal of Business Research 24(1), 297-312.

Nevins, J. L., Bearden, W. O. and Money, B. (2007). Ethical values and long-term orientation. Journal of Business Ethics 71, 261-274.

Parboteeah, K. P., Hoegl, M. and Cullen, J. B. (2008). Ethics and religion: An empirical test of a multidimensional model. Journal of Business Ethics 80, 387-398.

Pew Research. (2008). Unfavourable views of Jews and Muslims in the increase in Europe. Retrieved from http://www.pewglobal.org/2008/09/17/chapter-2-religiousness/

Pinto, M. B., Parente, D. H. and Palmer, T. D. (2000). Materialism and credit card use by college students. Psychological Report 86, 643-652.

Polonsky, M. J., Brito, P. Q., Pinto, P. and Higgs-Kleyn, N. (2001, May). Consumer ethics in the European Union: A comparison of northern and southern views. Journal of Business Ethics 31, 117-130. 
Rallapalli, K. C., Vitell, S. J., Wiebe, F. A. and Barnes, J. H. (1994). Consumer ethical beliefs and personality traits: An exploratory analysis. Journal of Business Ethics 13(7), 487-495.

Rashid, M. Z. and Ibrahim, S. (2007). The effect of culture and religiousness on business ethics: A cross-cultural comparison. Journal of Business Ethics 83, 907-917.

Ray, J. (2008). Indonesians champion religious freedom. Retrieved from http://www.gallup.com/poll/108160/Indonesians-Champion-Religious-Freedom.aspx

Rawwas, M. Y. A. (1996, September). Consumer ethics: An empirical investigation of the ethical beliefs of Austrian consumers. Journal of Business Ethics 15, 1009-1019.

Rawwas, M. Y. A. (2001). Culture, personality and morality: A typology of international consumers' ethical beliefs. International Marketing Review 18(2), 188-209.

Rawwas, M. Y. A., Patzer, G. and Klassen, M. (1995). Consumer ethics in cross cultural settings. European Journal of Marketing 29(7), 62-78.

Rawwas, M. Y. A., Patzer, G. and Vitell, S. J. (1998). A cross cultural investigation of the ethical values of consumers: The potential effect of war and civil disruption. Journal of Business Ethics 17(3), 435-448.

Rawwas, M. Y. A. and Singhapakdi, A. (1998, Spring). Do consumers' ethical beliefs vary with age: A substantiation of Kohlberg's Typology in marketing. Journal of Marketing Theory and Practice 6, 26-38.

Rawwas, M. Y. A., Strutton, D. and Johnson, L. W. (1996). An exploratory investigation of the ethical values of American and Australian consumers. Journal of Direct Marketing 10, 52-63.

Rawwas, M. Y. A., Vitell, S. J. and Al-Khatib, J.A. (1994). Consumer ethics: The possible effects of terrorism and civil unrest on the ethical values of consumers. Journal of Business Ethics 13(3), 223-231.

Reuters News Service. (2012). Direct foreign investment pours into Indonesia despite worries. Retrieved from http://www.reuters.com/article/2012/10/22/us-indonesia-economyfdi-idUSBRE89L04220121022.

Richins, M. L. and Dawson, S. (1992). A consumer values orientation for materialism and its measurement: Scale development and validation. Journal of Consumer Research 19(12), 303316.

Schneider, H., Krieger, J. and Bayraktar, A. (2011). The impact of intrinsic religiousness on consumers' ethical beliefs: Does It depend on the type of religion: A comparison of Christian and Moslem consumers in Germany and Turkey. Journal of Business Ethics 102, 319-332.

Singhapakdi, A., Rawwas, M. Y. A., Marta, J. and Ahmed, M. I. (1999). A cross-cultural study of consumer perceptions about marketing ethics. Journal of Consumer Marketing 16(3), 257-272. 
Socha, P. M. (1999). Ways religious orientations work: A Polish replication of measurement of religious orientations. The International Journal for the Psychology of Religion 9, 209-228.

Strutton, D., Scott, J., Vitell, S. J. and Pelton, L. E. (1994). How consumers may justify inappropriate behavior in market settings: An application on the techniques of neutralization. Journal of Business Research30, 253-260.

Suryadinata, L., Nurvidya, E. and Ananta, A. (2003). Indonesia's population: ethnicity and religion in changing political landscape. Institute of South East Asia Study (ISEAS). ISBN: 978-981-230-218-2.

Tsui, J. and Windsor, C. (2001). Some cross-cultural evidence of ethical reasoning. Journal of Business Ethics 31(2), 143-150.

Van Kenhove, P., Vermeir, I. and Verniers, S. (2001, August). An empirical investigation of the relationships between ethical beliefs, ethical ideology, political preference and need for closure. Journal of Business Ethics 32, 347-361.

Vitell, S. J. (2003). Consumer ethics research: Review, synthesis and suggestions for future. Journal of Business Ethics 43, 33-47.

Vitell, S. J. (2009). The role of religiousness in business \& consumer ethics: A review of the literature. Journal of Business Ethics, 90(2), 155-167.

Vitell, S. J., Anusorn Singhapakdi, A. and Thomas, J. (2001). Consumer ethics: An application and empirical testing of the Hunt-Vitell theory of ethics. Journal of Consumer Marketing 18(2), 153-178.

Vitell, S. J., Lumpkin, J. R. and Rawwas, M. Y. A. (1991, May). Consumer ethics: An investigation of the ethical beliefs of elderly consumers. Journal of Business Ethics, 10 365375 .

Vitell, S. J. and Muncy, J. (1992). Consumer ethics: An empirical investigation of factors influencing ethical judgments of the final consumer. Journal of Business Ethics 11, 585-597.

Vitell, S. J. and Muncy, J. (2005). The Muncy-Vitell consumer ethics scale: A modification and application. Journal of Business Ethics 62, 267-275.

Vitell, S. J. and Paolillo, G. P. (2003). Consumer ethics: The role of religiousness. Journal of Business Ethics 11, 151-162.

Vitell, S. J., Paolillo, J. G. P. and Singh, J. J. (2005). Religiousness and consumer ethics. Journal of Business Ethics 57, 175-181.

Vitell, S. J., Paolillo, J. G. P. and Singh, J. J. (2006). The role of money and religiousness in determining consumers' ethical beliefs. Journal of Business Ethics 64, 117-124.

Vitell, S. J., Singh, J. J. and Paolillo, J. (2007). Consumers' ethical beliefs: The roles of money, religiousness and attitude toward business. Journal of Business Ethics 73, 369-279. 
Vitell, S.J. (2010). The role of religiousness in business and consumer ethics: a review of literature. Journal of Business Ethics 90, 155-167.

Ward, S. and Wackman, D. B. (1971). Family and media influences on adolescent consumer learning. American Behavioral Scientist 14 (1-2), 415-427.

Weibe, K. F. and Fleck, J. R. (1980). Personality correlates of intrinsic, extrinsic and nonreligious orientations. Journal of Psychology 105, 181-187. 


\section{Appendix}

Table 1. Demographic Profile

\begin{tabular}{llc}
\hline Demographic & & Percentage \\
\hline Age & 18-20 years old & $48 \%$ \\
& $21-23$ years old & $39 \%$ \\
& $24-26$ years old & $9 \%$ \\
& 26 and above & $4 \%$ \\
Gender & Male & $55 \%$ \\
& Female & $45 \%$ \\
\multirow{4}{*}{ Marital status } & Single & $97 \%$ \\
& Married & $3 \%$ \\
\multirow{3}{*}{ Religion } & & \\
& Islam & $49 \%$ \\
& Christian/Catholic & $29 \%$ \\
& Buddhism & $12 \%$ \\
& Hinduism & $8 \%$ \\
& Others & $2 \%$ \\
\hline
\end{tabular}


Table 2. Scale Items

CONSUMER ETHICS (Vitell and Muncy, 2005); 1=strongly disagree; 5=strongly agree

Active, illegal

Returning damaged merchandise when the damage is your fault.

Giving misleading price information to a clerk for an unpriced item

Using a long distance access code that does not belong to you

Drinking a can of soda in a store without paying it

Reporting a lost item as stolen to an insurance company in order to collect the money.

\section{Passive}

Lying about a child's age in order to get a lower price.

Not saying anything when the waitress miscalculates the bill in your favour.

Observing someone shoplifting and ignoring it.

Getting to much change and not saying anything.

Active, legal

Using an expired coupon for merchandise.

Returning merchandise to a store by claiming it was a gift when it was not.

Using a coupon for merchandise you did not buy.

Not telling the truth when negotiating the price of a new automobile.

Stretching the truth on an income tax return.

\section{No harm/ no foul}

Installing software on your computer without buying it.

Burning a CD instead of buying it.

Using computer software or games that you did not buy.

Spending over an hour trying on different dresses and not purchasing any.

\section{Downloading}

Downloading music from the internet instead of buying it.

Buying counterfeit goods instead of buying the original manufacturers brands.

\section{Recycling}

Buying products labelled as "environmentally friendly" even if they don't work as well as competing products.

Purchasing something made of recycled materials even though it is more expensive.

Buying only from companies that have a strong record of protecting the environment.

Recycling materials such as cans, bottles, newspapers etc.

\section{Doing Good}

Returning to the store and paying for an item that the cashier mistakenly did not charge you for.

Correcting a bill that has been miscalculated in your favour.

Giving a larger than expected tip to a waiter or waitress.

Not purchasing products from companies that you believe don't treat their employees fairly. 
Table 2. Scale items (Continued)

MATERIALISM (Moschis and Churchill, 1978); 1=strongly disagree; 5=strongly agree

It is really true that money can buy happiness.

My dream in life is to be able to own expensive things.

People judge others by the things they own.

I buy some things that I secretly hope will impress other people.

Money is the most important thing to consider in choosing a job.

I think others judge me as a person by the kinds of products and brands I use.

LONG-TERM ORIENTATION (Bearden et al., 2006); 1=strongly disagree; 5=strongly agree

Long-term (tradition)

Respect for tradition is important to me.

Family heritage is important to me.

I value a strong link to my past.

Traditional values are important to me.

\section{Long-term (planning)}

I plan for the long term.

I work hard for success in the future.

I don't mind giving up today's fun for success in the future.

Persistence is important to me.

RELIGIOUSNESS (Allport and Ross, 1967); 1=strongly disagree; 5=strongly agree

\section{Intrinsic religiousness}

I enjoy reading about my religion.

It doesn't matter much what I believe so long as I am good (R).

It is important to me to spend time in private thought and prayer.

I have often had a strong sense of God's presence.

I try hard to live all my life according to my religious beliefs.

Although I am religious, I don't let it affect my daily life (R).

Although I believe in my religion, many other things are more important in life (R)

Extrinsic religiousness (social)

I go to a religious service because it helps me to make friends.

I go to a religious service to spend time with my friends.

I go to a religious service because I enjoy seeing people I know there.

Extrinsic religiousness (personal)

What religion offers me most is comfort in times of trouble and sorrow.

I pray mainly to gain relief and protection.

Prayer is for peace and happiness. 
Table 3. Correlation matrix: correlation Table: I-tailed significance

\begin{tabular}{|c|c|c|c|c|c|c|c|c|c|c|c|c|c|}
\hline Construct & 1 & 2 & 3 & 4 & 5 & 6 & 7 & 8 & 9 & 10 & 11 & 12 & 13 \\
\hline 1. ACTIVE & 0.715 & & & & & & & & & & & & \\
\hline 2. PASSIVE & $0.509 * *$ & 0.614 & & & & & & & & & & & \\
\hline 3. LEGAL & $0.541^{* *}$ & $0.612 * *$ & 0.727 & & & & & & & & & & \\
\hline 4. NO HARM & $-0.346 * *$ & $-0.140 * *$ & $-0.233 * *$ & 0.534 & & & & & & & & & \\
\hline 5. DOWLOADING & $0.125 *$ & $0.204 * *$ & $0.160 * *$ & 0.082 & 0.409 & & & & & & & & \\
\hline 6. RECYCLING & -0.178 & -0.003 & -0.059 & 0.080 & 0.071 & 0.722 & & & & & & & \\
\hline 7. DOINGGOOD & $-0.515 * *$ & $-0.453 * *$ & $-0.481 * *$ & $0.280 * *$ & $-0.124 *$ & 0.022 & 0.626 & & & & & & \\
\hline 8. INTRINSIC & $-0.515 * *$ & $-0.401 * *$ & $-0.457 * *$ & $0.328 * *$ & $-0.207 * *$ & 0.070 & $0.534 * *$ & 0.831 & & & & & \\
\hline 9. EXTRINSIC (SOCIAL) & $0.625 * *$ & $-0.450 * *$ & $0.501 * *$ & $-0.503 * *$ & $0.225 * *$ & -0.068 & $-0.593 * *$ & $-0.608 * *$ & 0.929 & & & & \\
\hline 10. EXTRINSIC (PERSONAL) & $-0.487 * *$ & $-0.353 * *$ & $-0.410 * *$ & $0.382 * *$ & $-0.198 * *$ & $0.114^{*}$ & $0.463 * *$ & $0.827 * *$ & $-0.599 * *$ & 0.772 & & & \\
\hline 11. MATERIALISM & -0.042 & 0.026 & 0.035 & $0.172 * *$ & $0.171 * *$ & $0.376^{* *}$ & -0.030 & 0.062 & -0.085 & $0.117 *$ & 0.890 & & \\
\hline 12. LTO (TRADITION) & $-0.484 * *$ & $-0.306 * *$ & $-0.377 * *$ & $0.431 * *$ & $-0.195 * *$ & 0.057 & 0.444 & $0.531 * *$ & $-0.602 * *$ & $0.575^{* *}$ & 0.043 & 0.509 & \\
\hline 13. LTO (PLANNING) & $-0.443 * *$ & $-0.337 * *$ & $-0.392 * *$ & $0.315 * *$ & $-0.159 * *$ & 0.030 & $0.498 * *$ & $0.509 * *$ & $-0.556 * *$ & $0.507 * *$ & -0.072 & $0.524 * *$ & 0.628 \\
\hline
\end{tabular}

$* p<0.01 * * p<0.005$

Coefficient alphas appear on the diagonal.

ACTIVE, Active/ Illegal; PASSIVE, Passive; LEGAL, Active/ Legal; NO HARM, No Harm/ No Foul; INTRINSIC, Intrinsic Religious Orientation; EXTRINSIC, Extrinsic

Religious Orientation; LTO, Long-Term Orientation. 
Table 4. Regression Analyses

Model

Standardized beta

$t$-value

Significance

(a) Dependent variable: active/illegal dimension

Constant

Intrinsic Religiousness $\quad-0.170$

7.782

0.000

Extrinsic Religiousness (Social) $\quad 0.402$

$-2.258$

$\mathbf{0 . 0 2 5}$

Extrinsic Religiousness (Personal) $\quad-0.007$

6.852

0.000

Materialism

0.003

$-0.089$

0.929

Long-term Orientation (Tradition) $\quad-0.111$

0.068

0.946

Long-term Orientation (Planning)

$\mathrm{R}^{2}=0.423$

$-0.072$

$-2.001$

0.046

Adjusted $\mathrm{R}^{2}=0.413$

F-value $=42.661$

$-1.358$

0.175

(b) Dependent variable: passive dimension

Constant

Intrinsic Religiousness $\quad-0.209$

Extrinsic Religiousness (Social) 0.312

Extrinsic Religiousness (Personal) $\quad 0.031$

Materialism

0.011

Long-term Orientation (Tradition) $\quad-0.075$

$-0.106$

Long-term Orientation (Planning)

$\mathrm{R}^{2}=0.236$

F-value $=18.001$

Adjusted $\mathrm{R}^{2}=0.223$

Significance $=\mathbf{0 . 0 0 0}$

$\begin{array}{rr}4.717 & \mathbf{0 . 0 0 0} \\ -2.414 & \mathbf{0 . 0 1 6} \\ 4.625 & \mathbf{0 . 0 0 0} \\ 0.356 & 0.722 \\ 1.178 & 0.239 \\ 0.174 & 0.862 \\ -1.227 & 0.220\end{array}$

(c) Dependent variable: active/legal dimension

Constant

6.073

0.000

Intrinsic Religiousness $\quad-2.222$

$-2.681$

0.008

Extrinsic Religiousness (Social) $\quad 0.310$

4.798

$\mathbf{0 . 0 0 0}$

Extrinsic Religiousness (Personal) $\quad 0.019$

0.203

0.818

Materialism

0.068

Long-term Orientation (Tradition) $\quad-0.039$

1.491

0.137

Long-term Orientation (Planning)

$-0.091$

$-0.645$

0.159

$\mathrm{R}^{2}=0.302$

$\mathrm{F}$-value $=25.119$

$-1.571$

0.117

Adjusted $\mathrm{R}^{2}=0.290$

Significance $=\mathbf{0 . 0 0 0}$

(d) Dependent variable: no harm/no foul dimension

Constant

Intrinsic Religiousness $\quad-0.115$

5.231

$\mathbf{0 . 0 0 0}$

$-1.388$

0.166

Extrinsic Religiousness (Social)

$-0.365$

$-5.654$

$\mathbf{0 . 0 0 0}$

Extrinsic Religiousness (Personal) $\quad 0.128$

1.525

0.128

Materialism

0.127

2.767

0.006

Long-term Orientation (Tradition)

0.184

3.014

$\mathbf{0 . 0 0 3}$

Long-term Orientation (Planning)

0.019

0.324

0.746

$\mathrm{R}^{2}=0.302$

F-value $=25.154$

Adjusted $\mathrm{R}^{2}=0.290$

Significance $=\mathbf{0 . 0 0 0}$

(e) Dependent variable: downloading

Constant

Intrinsic Religiousness $\quad-0.061$

4.117

$\mathbf{0 . 0 0 0}$

Extrinsic Religiousness (Social)

0.148

$-0.651$

0.516

2.021

0.044

$-0.063$

$-0.659$

0.510

Materialism

0.200

3.842

0.000

Long-term Orientation (Tradition)

$-0.063$

$-0.912$

0.362

Long-term Orientation (Planning)

$\mathrm{R}^{2}=0.099$

0.034

0.513

0.608

F-value $=6.427$

Adjusted $\mathrm{R}^{2}=0.084$

Significance $=\mathbf{0 . 0 0 0}$ 
Table 4. Regression analyses (continued)

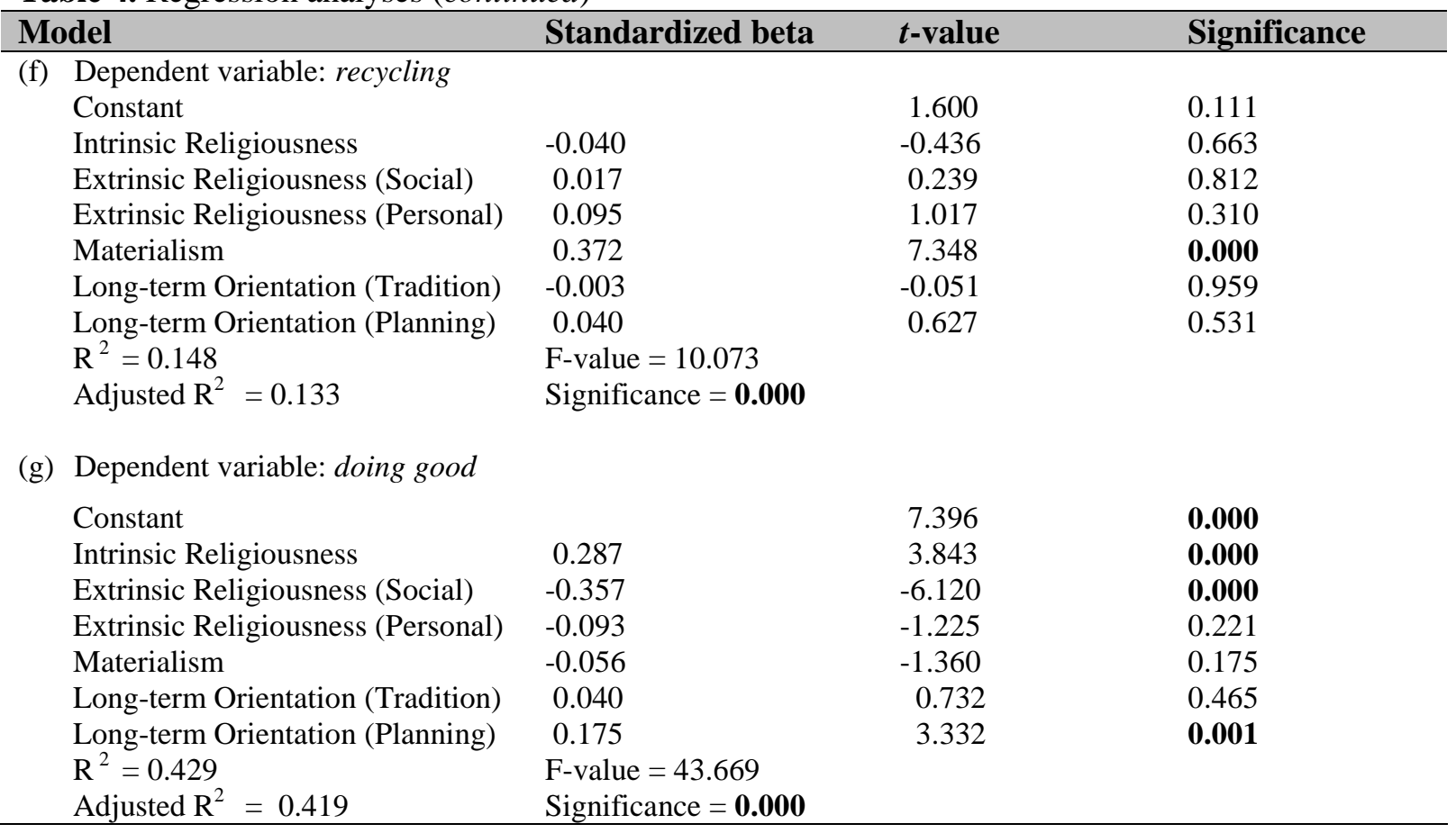


Table 5. Hypotheses testing results

\begin{tabular}{|c|c|c|c|}
\hline Hypothesis & Description & Finding ( $\beta$ sign $)$ & Conclusion \\
\hline \multirow[t]{8}{*}{$\mathbf{H}_{1}$} & $\begin{array}{l}\text { Intrinsic religiousness is a positive determinant of } \\
\text { consumer ethical beliefs regarding: }\end{array}$ & & \\
\hline & (a) "active, illegal" dimension & $(-)$ & Supported \\
\hline & (b) "passive" dimension & $(-)$ & Supported \\
\hline & (c) "active, legal" dimension & $(-)$ & Supported \\
\hline & (d) "no harm/no foul" dimension & (n.s) & Not supported \\
\hline & (e) "downloading" dimension & (n.s) & Not supported \\
\hline & (f) "recycling" dimension & (n.s) & Not supported \\
\hline & (g) "doing good" dimension & $(+)$ & Supported \\
\hline \multirow[t]{8}{*}{$\mathbf{H}_{2}$} & $\begin{array}{l}\text { Extrinsic religiousness (social and personal) is not } \\
\text { a significant determinant of consumer ethical } \\
\text { beliefs regarding: }\end{array}$ & & \\
\hline & (a) "active, illegal" dimension & Soc $(+), \operatorname{Per}($ n.s) & Soc (Not supported), Per (Supported) \\
\hline & (b) "passive" dimension & Soc $(+), \operatorname{Per}($ n.s) & Soc (Not supported), Per (Supported) \\
\hline & (c) "active, legal" dimension & Soc $(+), \operatorname{Per}($ n.s $)$ & Soc (Not supported), Per (Supported) \\
\hline & (d) "no harm/no foul" dimension & Soc $(-)$, Per (n.s) & Soc (Not supported), Per (Supported) \\
\hline & (e) "downloading" dimension & Soc $(+), \operatorname{Per}($ n.s) & Soc (Not supported), Per (Supported) \\
\hline & (f) "recycling" dimension & Soc (n.s), Per (n.s) & Soc (Supported), Per (Supported) \\
\hline & (g) "doing good" dimension & Soc (-), Per (n.s) & Soc (Not supported), Per (Supported) \\
\hline \multirow[t]{8}{*}{$\mathbf{H}_{3}$} & $\begin{array}{l}\text { Materialism is a negative determinant of consumer } \\
\text { ethical beliefs regarding: }\end{array}$ & & \\
\hline & (a) "active, illegal" dimension & (n.s) & Not Supported \\
\hline & (b) "passive" dimension & (n.s) & Not Supported \\
\hline & (c) "active, legal" dimension & (n.s) & Not Supported \\
\hline & (d) "no harm/no foul" dimension & $(+)$ & Supported \\
\hline & (e) "downloading" dimension & $(+)$ & Supported \\
\hline & (f) "recycling" dimension & $(+)$ & Not Supported \\
\hline & (g) "doing good" dimension & (n.s) & Not Supported \\
\hline \multirow[t]{8}{*}{$\mathbf{H}_{4}$} & $\begin{array}{l}\text { Long-term orientation (tradition and planning) is a } \\
\text { positive determinant of consumer ethical beliefs } \\
\text { regarding: }\end{array}$ & & \\
\hline & (a) "active, illegal" dimension & Tra (-), Pla (n.s) & Tra (Supported), Pla (Not Supported) \\
\hline & (b) "passive" dimension & Tra (n.s), Pla (n.s) & Tra (Not Supported), Pla (Not Supported) \\
\hline & (c) "active, legal" dimension & Tra (n.s), Pla (n.s) & Tra (Not Supported), Pla (Not Supported) \\
\hline & (d) "no harm/no foul" dimension & $\operatorname{Tra}(+)$, Pla (n.s) & Tra (Not Supported), Pla (Not Supported) \\
\hline & (e) "downloading" dimension & Tra (n.s), Pla (n.s) & Tra (Not Supported), Pla (Not Supported) \\
\hline & (f) "recycling" dimension & Tra (n.s), Pla (n.s) & Tra (Not Supported), Pla (Not Supported) \\
\hline & (g) "doing good" dimension & Tra (n.s), Pla (+) & Tra (Not Supported), Pla (Supported) \\
\hline
\end{tabular}

Notes: Soc $=$ Social; Per $=$ Personal; Tra $=$ Tradition $;$ Pla $=$ Planning; n.s = not significant. 